\title{
SELF-DIRECTED LEARNING READINESS (SDLR) AMONG FOUNDATION STUDENTS FROM HIGH AND LOW PROFICIENCY LEVELS TO LEARN ENGLISH LANGUAGE
}

\section{Lim Ying Xuan, ${ }^{1}$ Abu Bakar Razali \& Arshad Abd. Samad}

Department of English Language, Faculty of Humanities and Social Science, Southern University College, Jalan Selatan Utama, Off Jalan Skudai, 81300 Skudai, Johor.

Department of Language and Humanities Education, Faculty of Educational Studies, Universiti Putra Malaysia, 43400 UPM

Serdang, Selangor Darul Ehsan, Malaysia

${ }^{I}$ Corresponding author:abmr_bakar@upm.edu.my

Received: 31 May 2018 Revised: 8 November 2018 Accepted: 19 November 2018

\section{ABSTRACT}

Purpose - In the field of second language education, self-directed learning is really important as it can empower students to attain optimal success in language learning by engaging students to express their ideas confidently, think reflectively and make use of language learning strategies. The main aim of the present study is to investigate students' self-directed learning readiness (SDLR) in a foundation program in a public university in Malaysia so as to find out how they perceive this approach can improve their learning of the English language at tertiary level. More specifically, the researchers intend to find answers to these research questions: 1) Are foundation students ready to use self-directed learning strategies in English Language learning? (i.e. awareness, motivation and language learning strategies); 2) Is there a significant difference in the three attributes (i.e., awareness, motivation and language learning strategies) of self-directed learning among foundation students?; and 3) Is there a significant difference between English language proficiency (upper and lower) and the three attributes (i.e., awareness, motivation, language learning strategies) in using selfdirected learning strategies? 
Methodology - A set of survey questionnaires with a 6-point Likert scale were administered to 400 students attending an English proficiency course (i.e., Introduction to Academic English) in the first semester of the Foundation Studies for Agricultural Science program. The data of the questionnaire were analyzed using descriptive statistics, independent samples t-test and paired samples t-test.

Findings - Results revealed that the respondents have a rather high degree of readiness to apply self-directed learning strategies in learning English. Motivation has the highest mean scores ( $M=4.57)$, followed by language learning strategies $(\mathrm{M}=4.41)$ and awareness $(\mathrm{M}=4.34)$. Results also showed that there are no difference in terms of SDLR depending on English proficiency levels, namely lower level (MUET Bands 1,2,3) and upper level (MUET Bands 4,5) $(\mathrm{p}>.05)$.

Significance - The findings are beneficial for students to learn more about their readiness to apply the self-directed learning strategies. In particular, these findings also provide insights for lecturers, program administrators, curriculum developers, and policy makers to plan and implement suitable teaching methods, course outlines, and curricula for the development of the students' English language abilities.

Keywords: Self-directed learning readiness (SDLR), Motivation, Awareness, Language learning Strategies, Cognitive Strategies, Metacognitive Strategies.

\section{INTRODUCTION}

Over the years, the roles of language learners have been heavily discussed in the field of English Language learning (Kocak, 2003; Guglielmino, 2013; Mahboobe, 2014). As conceded by Tudor (1996), students play active and participatory roles in the learning process while teachers act as facilitators to motivate learners and help them acquire strategies needed for self-directed learning (Kocak, 2003). It is within this changing of perspective on the roles of teachers and learners that the concept of self-directed learning (SDL) began to gain popularity. Other terms which share a similar definition as self-directed learning have been adopted in literature, such as self-regulated learning, learner autonomy and independent 
learning (Kocak, 2003). In a broader sense, self-directed learning is the capacity to take charge of one's own learning (Holec, 1981). To be specific, self-directed learning can be defined as a process where the learner takes initiative to discover his or her needs during the process of learning, sets learning objectives, identifies resources, adopts suitable learning strategies and evaluates the outcomes (Knowles, 1975). Knowles (1975) also emphasized that it is the natural progression for language learners to pursue autonomous learning so as to learn and remember better in any given language learning situation. According to Reinders (2010), it is an integral part to help raise students' awareness of undertaking learning outside the classroom and preparing them on their path toward autonomy. In addition to awareness, it also requires students to have great amount of motivation as well as diversified learning strategies in order to be take the initiative to pursue a learning experience that is most beneficial in the long run. As such, gauging the level of selfdirected learning readiness is crucial as this will indicate whether one has the willingness, motivation and ability to participate in the task (Littlewood, 1999). Wiley (1983) defined self-directed learning readiness as the degree to which an individual possesses attitudes, abilities, and personality characteristics necessary for self-directed learning.

Based on the Malaysian National Education Policy Blueprint (2013-2025), the Malaysian education system aspires to develop students, especially those in tertiary education, with skills to drive independent learning and lifelong learning (Malaysian Education Blueprint 2013-2025 (Preschool-Post-Secondary Education, 2013). To achieve such goal, promoting autonomous mastery is essential to encourage English learners to take responsibility for their own English language learning, to boost their intrinsic motivation, to change their attitudes towards the English lessons, and to deal with challenges in their English language learning (see Garrison, 1997; Kocak 2003; Williamson, 2007; Yan, 2007; Steward, 2007; Dong, 2008). Activities involving critical thinking, creativity and problemsolving allow students to develop their sense of responsibility for their growth, for example, searching for information, commenting on information or sharing information (Saleh \& Tork, 2013). According to Reio (2003), risk tolerance and tolerance of ambiguity are higher among the learners with a higher level of self-directed learning readiness that can also lead to better academic performance. 
In addition, learner characteristics are vital in promoting selfdirected learning strategies in English language learning as well (Mahdavinia \& Nabatchi, 2011). Some research into self-directed learning and language proficiency demonstrates that self-directed learning strategy is a predictor of academic success (see Shien \& Akiko, 2009; Mahdavinia \& Nabatchi, 2011; Mohamadpour, 2013). In the present study, the researchers set out to uncover the readiness for students in a foundation program in a public university in Malaysia, involving both the upper and lower English language proficiency levels to see whether both levels of students are ready for self-directed learning, and in what ways teachers can help their learners incorporate a greater degree of learner autonomy in the learning and teaching process.

\section{Research Questions}

The present study seeks to address the following research questions:

1. Are foundation students ready to use self-directed learning strategies in English Language learning? (awareness, motivation and language learning strategies)

2. Is there a significant difference in the three attributes (awareness, motivation and language learning strategies) of self-directed learning among foundation students?

3. Is there a significant difference between English language proficiency (upper and lower) and the three attributes (awareness, motivation, language learning strategies) in using self-directed learning strategies?

\section{LITERATURE REVIEW}

\section{Motivation, Awareness and Language Learning Strategies}

This study is focused on three major constructs, i.e., motivation, awareness and learning strategies, which are accountable for selfdirected learning in English Language learning (see Garrison, 1997; Kocak, 2003; Williamson, 2007; Yan, 2007; Steward, 2007; Dong, 2008). Prior literature evidenced that more motivated students tended to use better strategies than less motivated students (Shien \& Akiko, 2009). Motivation is a prerequisite factor that influences the extent to which learners are ready to engage in self-directed learning, and 
teachers might have to ensure motivation before they train students to become self-directed learners (Spratt, Humphreys, \& Chan, 2002). Wolters (2003) further revealed that self-directed learners tend to be more motivated intrinsically, while they less motivated by external factors such as rewards, scores or threats.

Together with motivation, awareness is also considered to be crucial in the self-directed learning process. As contended by Sinclair (1999), "without an explicit and conscious awareness of the processes involved in learning a language, learners will not be in a position to make informed decisions about their own learning" (p.99). In other words, learners should be highly aware of the idea that their own efforts are pivotal to progress in learning by monitoring their own performance and voluntarily trying to do their best so that they could apply the acquired skills consciously (Scharle \& Szabo, 2000). Therefore, it has become vitally paramount for teachers stress the importance of 'learning to learn' in language learning and to make learners aware of the processes. This can result in the use of appropriate learning strategies that best suit English language learners' needs.

Apart from that, self-directedness demands learners to gain learning strategies for input, comprehension and output of target language. Rivero, Urquía, López, and Camacho (2017) argued that it is insufficient if students are motivated to attain high grades, as learning strategies are so essential for greater achievement in autonomous learning. Much literature has also emphasized the importance of both cognitive and metacognitive strategies in boosting self-directed learning in language (Kocak, 2003; Dong \& Xin, 2005; Du, 2013). Cotterall (1999) emphasized that metacognitive strategies commonly consist of planning, monitoring and evaluating required for selfdirected learning. In addition, cognitive strategies also need to be applied by self-directed learners to facilitate varied learning situations to solve learning problems more effectively. O’Malley (1987) argued that cognitive strategies "operate directly on incoming information, manipulating it in ways that enhance learning" (p.244). Examples of cognitive strategies include questioning for clarification, utilizing resources like dictionaries, translation, note taking and deduction of second language rules (O’Malley, 1987).

However, there were scarce attempts to consider self-directed learning readiness (i.e., motivation, awareness, language learning 
strategies) of foundation students as well as the differences of the three attributes between high proficiency learners and their counterparts. Hence, the ultimate goal of this project is to explore students' interests, thus increasing their motivation in learning, and to be focused to assess students' awareness of their capabilities as to utilize learning strategies more fully. By understanding self-directed learning readiness (i.e., motivation, awareness, language learning strategies) toward English language learning, the results can point out the need to modify curriculum and to better develop teaching practices to ensure a smoother transition from the secondary education level to the tertiary education level among students from basic foundation course.

\section{Self-Directed Learning Readiness toward Language Learning}

This paper draws upon literature concerned with self-directed learning. Several studies such as Kocak (2003), Yan (2007) and Shien and Akiko (2009) revealed that there are vast differences between the respondents' gender, proficiency level and major field as well as attributes for self-directed learning readiness. One of the results revealed that teachers' teaching methods, which were not based on students' true needs and expectations, to some extent, hindered students from experiencing a greater degree of autonomy in language learning (Shien and Akiko, 2009).

Moreover, several studies have outlined benefits which selfdirected learning can bring about. According to a research study by Khodabandehlou et al. (2012), it was confirmed that learners who were equipped with SDL strategies, in particular metacognitive strategies, outperform those who experienced teacher-directed learning (TDL) after treatment. Du's (2013) findings confirmed that SDL portfolio project is an effective learning strategy for students who learn foreign languages because this could result in improvements in knowledge domain (e.g., understanding of vocabulary and news structure), metacognitive skills, and motivation.

In short, even though gender, academic achievement, motivation, attitudes, awareness, language proficiency and language learning strategies have long interested researchers in the study of selfdirected learning readiness, there are no general agreements in terms of their results. Apart from this, there are various kinds of instruments 
being utilized in quantitative study. As a result, this present research attempts to shed light on three constructs, i.e. awareness, motivation and language learning strategies to further confirm or expand upon the results in the previous studies. As a result, questionnaires employed previously in diversified learning contexts were adapted and modified by incorporating sub areas that fit in English language learning to contribute to the current SDLR knowledge base.

\section{Theoretical Framework}

There are two dominant theories of learning that are directly connected with learner autonomy, which are humanism and constructivism. Modern education places great emphasis on the development of humanistic education based on the belief that "learners should have a say in what they should be learning and how they should learn it, and reflects the notion that education should be concerned with the development of autonomy in the learner" (Nunan, 1988, p. 20). The humanistic movement has a significant influence on language teaching and communicative activities. Dubin and Olshtain (1986) (as cited in Wenden, 1991) have suggested ways for teachers to promote learner autonomy in the classroom. For instance, to show respect and value on the learner, to view learning as a form of self-realization, to offer learners a large number of opportunities in the decision making process, and to play the role of facilitator. Moreover, autonomous learners should be taught and expected to use metacognitive strategies involving self-monitoring, self-evaluation, and so on (Kocak, 2003).

Meanwhile, Kerka (1997) defined constructivism as a situation where, "learners actively construct knowledge by integrating new information and experiences into what they have previously come to understand, revising and reinterpreting old knowledge in order to reconcile it with the new" (p. 1). In this learning paradigm, instructors can support students' learning constructivism by asking good questions, listening to students' needs, and creating environments that allow students to make choices that reinforce the overall goals for courses (Reeve, 2009). In language learning context, autonomous learners tend to draw upon existing grammatical knowledge and vocabulary, or prior experience and to examine, analyze, and interpret them based on what they have come across to enhance language competence. 


\section{METHODOLOGY}

\section{Participants}

A cluster sampling method was administered by selecting a sample of 400 students from a population of 730 foundation students on campus. Every student was selected from 18 classes out of the 30 existing classes. The foundation program that offers them another pathway to enter university for the bachelor's degree level is intensive, where they are required to complete educational subjects, such as biology, chemistry, mathematics, physics, English, computer science as well as other agricultural courses (Kuah, 2007). The respondents were undertaking a compulsory English course, i.e., Introduction to Academic English, which aims to impart skills related to English language proficiency, such as note-making in English, summarizing English texts, presentation skills in English, and so on. Each of the respondents in this study has sat for the Malaysian University English Test (MUET), which is a prerequisite entrance examination in applying for admissions into public universities and colleges. The scores are graded in six bands, with Band 6 being the highest band and Band 1 being the lowest band (MUET - Portal Rasmi Majlis Peperiksaan Malaysia, 2017).

\section{Research Instruments}

A survey questionnaire was administered to elicit learners' selfdirected learning readiness. In this survey questionnaire, a 6-point Likert-like measurement scale was employed ranging from strongly disagree "1" to strongly agree "6". Part A of the instrument was designed to gather demographic information of respondents, such as MUET (Malaysian University English Test) band results while Part B of the instrument was meant to measure 44 items which were categorized under three constructs of self-directed learning (i.e. motivation, awareness and language learning strategies). Many of the items were adapted and modified from existing instruments, such as 23 items from Learner Autonomy Readiness Instrument (LARI) (Kocak, 2003); 9 items from Self-Rating Scales of SelfDirected Learning (SRSSDL) (Williamson, 2007); 12 items from Self-Directed Learning Readiness Scale (SDLRS) (Steward \& Yan, 2007). Four English language instructors with the qualifications of Master in TESL at the university were also involved to improve the existing questionnaires. 


\section{Validity and Reliability}

In this study, the content validity of the questionnaire was established following the review of related literature and through the appraisal of the academicians who were actively participating in English Language teaching. They were requested to evaluate the consistent themes and items found in the literature. A comparison of existing instruments was conducted based on research authored by Kocak (2003), Williamson (2007), Yan (2007) and Steward (2007). They were asked to indicate whether they feel the statements were consistent or inconsistent with respect to the description of the instrument, comment on the wording of the items, suggest missing items, delete ambiguous items and assess the instrument structure and instructions for use. All comments were subsequently reviewed and the necessary changes were made in light of the comments. Also, to ensure the instrument was reliable and fit for use, a sample of 50 foundation students was randomly selected for a pilot study. The respondents were asked to comment on the clarity of the items in the instrument. Following the pilot test, the reliability test of the instruments has been assessed using Statistical Package of the Social Science (SPSS) Statistics 22. From the pilot study, the Cronbach's alpha values for each section were as follows: Motivation (0.815), Awareness (0.818) and Learning strategies (0.922) which indicated that there was a high internal consistency between the items. In addition to the pilot study, the reliability of the instrument has been empowered with literature and brainstorming sessions. Upon completion of the actual data collection, the reliability of the items were analyzed and compared to the pilot study again to confirm the consistencies of the items.

\section{Data Collection Procedure}

Prior to data collection, verbal permission was obtained from the Director of the Foundation Studies for Agricultural Science program in the university. A pilot test was also carried out with 50 respondents being excluded from the actual study. Upon the completion of the pilot study, the researchers checked the reliability of the instrument through SPSS Statistics 22 software program. The respondents' opinions from the pilot study were taken into consideration for modifications. The final draft of the survey instrument was administered to 400 foundation students from 18 different classrooms who were contacted through their classroom instructors. The researcher took 
5 minutes to brief the survey topic and its aims with the respondents in their classrooms. Subsequently, the respondents were given 10 minutes to complete the questionnaires which were distributed by the researcher.

\section{Data Analysis}

The descriptive analysis was done in order to answer the first research question, in which means and standard deviations of the three constructs of self-directed learning readiness were analyzed. The higher the mean, the higher the readiness for self-directed in English Language learning and vice versa. In answering the second research question, the means of the three constructs were compared and tested using pairing, for instance motivation-awareness, motivation-language learning strategies, and awareness-language learning strategies in order to see if there was any significant difference in the three attributes of SDL, namely: awareness, motivation, and learning strategies. Finally, independent samples t-tests were conducted to examine the variations of the three selfdirected learning attributes according to proficiency levels by testing and comparing the means of the three attributes with regards to selfdirected learning readiness, i.e., motivation, awareness and language learning strategies in learning English.

\section{RESULTS}

\section{Three Attributes for Self-Directed Learning Readiness of Foundation Students in English Language Learning}

Table 1 provides details of the means and standard deviations for the 44 items which constitute the three attributes of SDLR, namely: motivation (M), awareness (A) and language learning strategies (L). Based on the overall findings from the survey, the respondents were perceived to have intrinsic motivation for English language learning $(\mathrm{M}=4.57 ; \mathrm{SD}=.65)$. This was followed by the second rating attribute, language learning strategies $(\mathrm{M}=4.41 ; \mathrm{SD}=.67)$, whereas awareness was the lowest rating attribute with a mean value of 4.34 and $\mathrm{SD}=.65$. As noted earlier, given the use of a 6-point Likert-like measurement scale ranging from strongly disagree "1" to strongly agree " 6 ", the mean scores 0-2.00 indicates 'low'; the mean scores 2.01-4.00 indicates 'medium'; the mean scores above 4.01 indicates 
'high' Generally, the mean scores for the three attributes were rather high and this indicates that some students possess relatively high readiness to take responsibility for English Language learning (M $>4.01)$. Further explanation of each of these findings is presented below.

Table 1

Self-Directed Learning Readiness Items, Mean, Standard Deviation and Total Number of Respondents $(N=400)$

\begin{tabular}{|c|c|c|c|}
\hline $\begin{array}{l}\text { Item } \\
\text { Code }\end{array}$ & Item & Mean & $\begin{array}{l}\text { Standard } \\
\text { Deviation }\end{array}$ \\
\hline $\mathbf{M}$ & Motivation (Overall) & 4.57 & .65 \\
\hline M2 & $\begin{array}{l}\text { I will try to learn English although it } \\
\text { may be difficult. }\end{array}$ & 4.97 & .81 \\
\hline M3 & I try to do my best to learn English. & 5.01 & .80 \\
\hline M4 & $\begin{array}{l}\text { Even if there is no attendance } \\
\text { requirement in the English course, } \\
\text { my attendance will be high. }\end{array}$ & 4.44 & 1.10 \\
\hline M5 & $\begin{array}{l}\text { I want to continue learning English } \\
\text { for as long as possible. }\end{array}$ & 4.72 & 1.01 \\
\hline M6 & $\begin{array}{l}\text { I believe that I will do well in the } \\
\text { English class. }\end{array}$ & 4.61 & .86 \\
\hline M7 & $\begin{array}{l}\text { I want to be the best in the English } \\
\text { class. }\end{array}$ & 4.72 & .96 \\
\hline M8 & I like to speak English in the class. & 4.48 & 1.03 \\
\hline M9 & $\begin{array}{l}\text { I want to learn how to use English } \\
\text { language effectively. }\end{array}$ & 5.23 & .85 \\
\hline M10 & $\begin{array}{l}\text { I do English grammar exercises even } \\
\text { though it is not homework. }\end{array}$ & 3.06 & 1.13 \\
\hline M11 & $\begin{array}{l}\text { I study English due to interest in } \\
\text { English culture, such as English } \\
\text { films, sports, music, etc. }\end{array}$ & 4.62 & 1.20 \\
\hline M12 & I study English due to curiosity. & 4.17 & 1.17 \\
\hline $\mathbf{A}$ & Awareness (Overall) & 4.34 & .65 \\
\hline A1 & $\begin{array}{l}\text { I identify my own English Language } \\
\text { learning needs. }\end{array}$ & 4.58 & .98 \\
\hline
\end{tabular}




\begin{tabular}{|c|c|c|c|}
\hline $\begin{array}{l}\text { Item } \\
\text { Code }\end{array}$ & Item & Mean & $\begin{array}{l}\text { Standard } \\
\text { Deviation }\end{array}$ \\
\hline A2 & $\begin{array}{l}\text { I am able to select the best } \\
\text { method for my own English language } \\
\text { learning. }\end{array}$ & 4.08 & 1.04 \\
\hline A3 & $\begin{array}{l}\text { I consider English teachers as } \\
\text { facilitators of learning rather than } \\
\text { the providers of information only. }\end{array}$ & 4.97 & .96 \\
\hline A4 & $\begin{array}{l}\text { I keep myself up to date on different } \\
\text { learning resources available to } \\
\text { improve my English Language } \\
\text { proficiency. }\end{array}$ & 4.13 & 1.03 \\
\hline A5 & $\begin{array}{l}\text { I am able to learn English despite } \\
\text { not being instructed by a language } \\
\text { instructor. }\end{array}$ & 4.01 & 1.14 \\
\hline A6 & $\begin{array}{l}\text { I am responsible for my own English } \\
\text { Language learning. }\end{array}$ & 4.52 & 1.07 \\
\hline A7 & $\begin{array}{l}\text { I am responsible for identifying my } \\
\text { areas of weaknesses and strengths in } \\
\text { my English language proficiency. }\end{array}$ & 4.67 & .99 \\
\hline A8 & $\begin{array}{l}\text { I am able to plan and set my English } \\
\text { language learning goals. }\end{array}$ & 4.16 & 1.01 \\
\hline A9 & $\begin{array}{l}\text { I relate my experience to new } \\
\text { information when I learn English. }\end{array}$ & 4.47 & 1.00 \\
\hline A10 & $\begin{array}{l}\text { I can still learn English well by } \\
\text { myself without attending classes. }\end{array}$ & 3.41 & 1.21 \\
\hline A11 & $\begin{array}{l}\text { In English learning, learners must be } \\
\text { active and teachers can only assist } \\
\text { their English learning. }\end{array}$ & 4.62 & 1.00 \\
\hline A12 & $\begin{array}{l}\text { I like to learn English in pairgroup } \\
\text { discussion. }\end{array}$ & 4.50 & 1.22 \\
\hline $\mathbf{L}$ & $\begin{array}{l}\text { Language Learning } \\
\text { Strategies (Overall) }\end{array}$ & 4.41 & .67 \\
\hline L1 & $\begin{array}{l}\text { When I am learning a new grammar } \\
\text { rule, I think about its relationship and } \\
\text { the rules I have already learned. }\end{array}$ & 4.30 & 1.04 \\
\hline $\mathbf{L} 2$ & $\begin{array}{l}\text { When I study English, I write down } \\
\text { the most important points for myself }\end{array}$ & 4.41 & 1.06 \\
\hline L3 & $\begin{array}{l}\text { I try to find the meaning of a word or } \\
\text { phrase by breaking it up into parts that I } \\
\text { can understand. }\end{array}$ & 4.77 & 1.00 \\
\hline
\end{tabular}




\begin{tabular}{|c|c|c|c|}
\hline $\begin{array}{l}\text { Item } \\
\text { Code }\end{array}$ & Item & Mean & $\begin{array}{l}\text { Standard } \\
\text { Deviation }\end{array}$ \\
\hline L4 & $\begin{array}{l}\text { I read English written materials to } \\
\text { improve my English (e.g., English } \\
\text { magazines, books, newspapers) }\end{array}$ & 4.62 & 1.06 \\
\hline L5 & $\begin{array}{l}\text { I listen to English materials to im- } \\
\text { prove my English. (e.g., English } \\
\text { songs, news, radio broadcasts) }\end{array}$ & 5.07 & 1.00 \\
\hline L6 & $\begin{array}{l}\text { I always ask my teacher for clarifica- } \\
\text { tion when an idea is not clear. }\end{array}$ & 4.16 & 1.10 \\
\hline L7 & $\begin{array}{l}\text { I intentionally apply English that I } \\
\text { have learned for communication. } \\
\text { (e.g., speaking, writing) }\end{array}$ & 4.53 & .99 \\
\hline L8 & $\begin{array}{l}\text { When I see a word I don't understand, } \\
\text { I ask others for its meaning. }\end{array}$ & 5.02 & .92 \\
\hline L9 & $\begin{array}{l}\text { When I see a word I don't understand, } \\
\text { I look it up in the dictionary. }\end{array}$ & 4.73 & 1.10 \\
\hline L10 & $\begin{array}{l}\text { During class, I make use of any op- } \\
\text { portunity to take part in activities } \\
\text { such as pair/group discussion, role- } \\
\text { play etc. }\end{array}$ & 4.01 & 1.09 \\
\hline L11 & $\begin{array}{l}\text { When learning English, I try to iden- } \\
\text { tify language structures and terms I } \\
\text { do not understand well. }\end{array}$ & 4.50 & .96 \\
\hline L12 & $\begin{array}{l}\text { I understand the importance of mak- } \\
\text { ing my teacher's teaching objective } \\
\text { as my own learning goal. }\end{array}$ & 4.44 & .94 \\
\hline L13 & $\begin{array}{l}\text { When I feel that a learning method is } \\
\text { not appropriate, I use other learning } \\
\text { methods. }\end{array}$ & 4.54 & .99 \\
\hline L14 & $\begin{array}{l}\text { I evaluate my learning methods to } \\
\text { find out the problems and solutions. }\end{array}$ & 4.36 & .98 \\
\hline L15 & $\begin{array}{l}\text { If I feel left behind in class, I will } \\
\text { practice more outside the classroom } \\
\text { to catch up with others. }\end{array}$ & 4.33 & 1.11 \\
\hline L16 & $\begin{array}{l}\text { I formulate my own English study } \\
\text { plan besides what the teacher teaches } \\
\text { in the classroom. }\end{array}$ & 3.92 & 1.15 \\
\hline L17 & $\begin{array}{l}\text { I keep a record of my performance, } \\
\text { such as keeping a diary, writing } \\
\text { review etc. }\end{array}$ & 3.44 & 1.25 \\
\hline
\end{tabular}




\begin{tabular}{clcc}
\hline $\begin{array}{l}\text { Item } \\
\text { Code }\end{array}$ & Item & Mean & $\begin{array}{c}\text { Standard } \\
\text { Deviation }\end{array}$ \\
\hline L18 & $\begin{array}{l}\text { I check and renew my understanding } \\
\text { of English language I have previously } \\
\text { learned in class. }\end{array}$ & 3.92 & 1.11 \\
& $\begin{array}{l}\text { I choose English contents which suit } \\
\text { me for practice that are neither too }\end{array}$ & 4.59 & .94 \\
& $\begin{array}{l}\text { difficult nor too easy. } \\
\text { L20 }\end{array}$ & $\begin{array}{l}\text { I set up English Language learn- } \\
\text { ing objectives based on my actual } \\
\text { needs. }\end{array}$ & 4.49 \\
\hline
\end{tabular}

As for the first attribute of self-directed learning readiness, the respondents appeared to have a high intrinsic motivation for learning English. As drawn from the data, most of the mean values were over 4.01, such items as M9=5.23 and M3=5.01 reflected that respondents were engaged in the process of English language learning in order to know how to use the language effectively and enjoyed the learning process.

In terms of awareness as a self-directed learning readiness attribute, the mean scores of item A3 (M=4.97) illustrated that the respondents were aware of the roles English teachers play as facilitators of learning as well as the providers of information. On a related note, the respondents showed certain agreement (e.g., with the second highest mean of 4.67 for item A7; 4.62 for item A11; 4.58 for item A1; 4.52 for item A6; 4.50 for item A12).

Table 1 also illustrates the data of the usage of language learning strategies, i.e., cognitive strategies from statements L1 to L11 and metacognitive strategies from statements L12 to L20. As can be seen in Table 1, L5, which is an item for a cognitive strategy, with the highest mean score of 5.07, revealed that the respondents tended to get accustomed to listening English materials in improving their English (e.g., English songs, news, radio broadcasts). Following L5, the second and third highest mean scores of 5.02 for L8 and 4.77 for L3, which are both cognitive strategies, exhibited respondents' agreements to the utilization of deduction and questioning for clarification to attain their English language learning goals. In contrast to this, the three lowest rated language learning strategies ranging from $3.44(\mathrm{~L} 17)$ to $3.92(\mathrm{~L} 16, \mathrm{~L} 18)$ items which are related 
to metacognitive strategy, in particular, evaluating one's own performance $(\mathrm{L} 18=3.92)$, formulating one's own plans $(\mathrm{L} 16=3.92)$ and keeping record of learning performance $(\mathrm{L} 17=3.44)$. Based on the results reported by the respondents, metacognitive strategies were the least useful strategies to be adopted for English learning.

\section{Difference between Levels of Self-Directed Learning Readiness Attributes in English Language Learning among Foundation Students}

Table 2 presents information about the paired samples t-test conducted to compare the means among motivation level, awareness level and the level of the use of language learning strategies.

Table 2

Paired Samples t-Test Results Comparing Motivation, Awareness and Language Learning Levels

\begin{tabular}{|c|c|c|c|c|c|c|}
\hline $\begin{array}{l}\text { Attribute } \\
\text { Level }\end{array}$ & $\begin{array}{l}\text { Mean } \\
\text { Difference }\end{array}$ & $\begin{array}{l}\text { Std. } \\
\text { Deviation }\end{array}$ & $\begin{array}{l}95 \% \\
\text { Conf } \\
\text { Inter } \\
\text { the L } \\
\text { Low } \\
\text { Upp }\end{array}$ & $\begin{array}{l}\text { nce } \\
\text { of } \\
\text { eence }\end{array}$ & $\mathrm{t}$ & $\begin{array}{l}\text { Sig. } \\
\text { (2-tailed) }\end{array}$ \\
\hline $\begin{array}{l}\text { Motivation- } \\
\text { Awareness }\end{array}$ & .22 & .51 & .17 & .27 & 8.72 & .00 \\
\hline $\begin{array}{l}\text { Motivation- } \\
\text { Language } \\
\text { Learning } \\
\text { Strategies }\end{array}$ & .16 & .50 & .11 & .21 & 6.43 & .00 \\
\hline $\begin{array}{l}\text { Awareness } \\
\text { Language } \\
\text { Learning } \\
\text { Strategies }\end{array}$ & -.06 & .44 & -.11 & -.02 & -2.85 & .005 \\
\hline
\end{tabular}

As shown in Table 2, in pair 1 (motivation-awareness), there was evidence ( $\mathrm{t}(399)=8.72, \mathrm{p}=.00)$ to suggest that participants experienced statistically significantly greater motivation than awareness (mean difference $=0.22, \mathrm{SD}=.51$ ) in exercising selfdirected strategy to make improvement in English language learning. 
One of the plausible factors is that despite being motivated learners, respondents are less aware of their roles to share or shoulder responsibility to make progress in English learning. Another evidence on pair 2 (motivation-language learning strategies), (t (399) $=6.43$, $\mathrm{p}=.000$ ) also revealed that there was a statistically significant mean difference between motivation and language learning strategies (mean difference $=.16, \mathrm{SD}=.50$ ). This further suggested that the learners were significantly motivated as compared to their abilities in utilizing language learning strategies to overcome problems in learning English Language. Moreover, the difference in pair 3 (awareness-language learning strategies) also indicated that the awareness level for self-directed learning in the field of English language (mean difference $=-.06 ; \mathrm{SD}=.44$ ) was lower than the degree of the use of language learning strategies; $\mathrm{t}(399)=-2.85, \mathrm{p}=.005$. It was also revealed that respondents had lower level of awareness for the readiness on active participation in English learning, even though they reported to have adopted a wide range of approaches in the process of autonomous learning in the learning of English.

\section{Difference between Attributes of Self-directed Learning Readiness according to English Proficiency Levels}

An independent samples t-test was conducted to investigate whether there was any statistical difference in the three attributes of selfdirected learning readiness, i.e., motivation, awareness and language learning strategies in learning English according to proficiency levels. In this study, the proficiency levels of English is divided into two main categories which are lower proficiency level (Bands 1, 2, and 3) and upper proficiency level (Bands 4 and 5) according to participants' MUET (Malaysia University English Test) results. The results of the t-test are presented in Table 3.

Notably, there was no significant mean difference $=-.086$ between lower and higher proficiency level students in terms of motivation level; $\mathrm{t}(397)=-1.13, \mathrm{p}=.26$. In other words, students of lower and higher English proficiency did not have any significant difference in terms of the level of motivation to show readiness in becoming selfdirected learners for making progress in English. In a similar vein, the mean difference $=-0.11$ in relation to awareness level of the respondents from both proficiency levels did not differ significantly (t $(397)=-1.44, p=.15)$. That is, students with lower and upper level of English proficiency showed no difference in the degree of 
awareness regarding readiness on self-directed learning in mastering English.

Table 3

Independent samples t-Test Results for Attributes of Self-directed Learning Readiness according to Proficiency Levels

\begin{tabular}{llllll}
\hline Attribute Level & $\begin{array}{l}\text { Mean } \\
\text { Difference }\end{array}$ & $\begin{array}{l}\text { 95\% of Confidence } \\
\text { Interval of the } \\
\text { Difference } \\
\text { Lower }\end{array}$ & Upper & & $\begin{array}{l}\text { Sig. } \\
\text { (2-tailed) }\end{array}$ \\
\hline Motivation & -.086 & -.24 & -.64 & -1.13 & .26 \\
$\begin{array}{l}\text { Awareness } \\
\text { Language }\end{array}$ & -.11 & -.25 & .39 & -1.44 & .15 \\
$\begin{array}{l}\text { Learning } \\
\text { Strategies }\end{array}$ & .033 & -.11 & .18 & .44 & .66 \\
\hline
\end{tabular}

Note. One missing case for MUET results.

The result drawn from this data also indicated that the mean difference $=.033$ linked to the language learning strategies did not differ significantly by considering their language proficiency levels $(\mathrm{t}(397)=.44, \mathrm{p}=.66)$. It may be inferred that the language learning strategies adopted by upper and lower English proficiency students did not differ. To sum up, students with lower and upper proficiency levels have the similar level of motivation, awareness and language learning strategies.

\section{DISCUSSION}

\section{Three Attributes for Self-Directed Learning Readiness of Foundation Students in English Language Learning}

From the analysis of the self-reported results that are linked with the three attribute levels of readiness in relation to self-directed learning in English Language learning (see Table 1), some encouraging results were observed. Based on the highest mean score of motivation (4.57), the result indicated students' strong determination to learn English language despite of learning obstacles to fulfill academic 
requirement in their transitional period, which is the foundation level of their studies before moving towards undergraduate studies. One interesting point to note here is that respondents were more interested in radio programs, English films, songs and other authentic English communicational opportunities beyond the language classroom context over monotonous grammar exercises. This was reflected in the difference in mean scores between M11 (4.62) which refer to students' interest in authentic materials. Therefore, it might be argued that meaning-focused input activities are highly valued among self-directed learners.

Meanwhile, the awareness level of self-directed learning readiness, which has the second highest mean score (4.34) among the three attributes, demonstrated that teachers were regarded as both facilitators of learning rather than information providers (see $\mathrm{A} 3=4.97$ ) as well as the importance to be active learners (A11=4.62). In contrast to the higher level of agreement, the lower mean score of A10 (3.14) suggested that learners lack the abilities to learn English well without attending classes or assistance from teachers. It may also be an indicator of the exposure to traditional educational methods in an English language learning classroom that hinders students to experience a greater degree of autonomy as a result of the teacher's dominant authority to decide the lesson plan of English course and select the relevant activities or materials, such as module study guide, textbooks and handouts (Little, 1990).

Table 1 earlier also illustrates participants' responses to the selfdirected learning readiness level about the usage of language learning strategies, i.e., cognitive strategies and metacognitive strategies. As can be seen from the findings, it is noteworthy that metacognitive strategies were perceived to be of less usefulness in learning English language, including evaluating own understanding (L18=3.92), formulating one's own plans (L16=3.92) and keeping record of learning performance $(\mathrm{L} 17=3.44)$. Notwithstanding, the respondents reported a greater level of agreement $(\mathrm{M}>5.0)$ on using cognitive strategies which are contextualization (L5=5.07), question for clarification and (L8=5.02) and deduction (L3=4.77). Albeit argument being indicated in some studies that metacognitive strategies can help grow learners' motivation and lessen their dependence on teacher (e.g., Kocak, 2003; Khodabandehlou et al., 2012), the respondents in this particular study seemed to not show as much agreement on these strategies as they reported towards cognitive strategies for their independent learning. 


\section{Difference between Levels of Self-Directed Learning Readiness Attributes in English Language Learning among Foundation Students}

In order to answer research question two, a paired samples t-test was implemented to compare the means among motivation level, awareness level, and the level of the use of language learning strategies. A major trait of respondents' readiness for self-directed learning in English language learning was observed based on the statistical evidence (t $(399)=8.72, \mathrm{p}=.00)$ of pair 1 (motivationawareness) in Table 2. It demonstrated that participants had greater motivation than awareness for learner's responsibility in English Language learning. This finding may arise from the fact that students pursuing foundation studies are highly intrinsically motivated to thrive in the English academic achievement to prepare for campus life and ensure the chances to go to university. This finding, especially in the Malaysian undergraduate students' context, is also in line with the study by Abdullah (2016) which offers insights on the interaction effects between motivational beliefs, and gender and self-regulated learning. Abdullah (2016) found that self-efficacy and control beliefs were positively related to students 'self-regulated learning. Anxiety, however, was found to be negatively related to self-regulated learning. It is important to note, however, to create awareness of learner autonomy in English language learning in the university, which is in line with the strategic initiative outlined in the Malaysian Education Blueprint 2013-2025 to empower tertiary students (Preschool-Post-Secondary Education, 2013), students should be encouraged to apply their knowledge in their daily English learning activities, for instance study planning, data-collecting, selfsupervising, oral and written communication, collaborative learning, peer evaluating and so forth (Wang, 2010; Bhrathi, 2014).

On top of this, an additional readiness attribute in self-directed learning for English language may be observed in accordance to the statistical evidence $t(399)=8.72, p=.00$ of pair 2 (motivationlanguage learning strategies) in Table 2. It was found that the learners were more proactive to increase their English competence, but less aware of language learning strategies to take charge of their learning. The results may imply that learners held high intrinsic motivation in self-directed learning, yet lack the techniques to learn autonomously throughout the English learning process. 
Based on the findings in the paired samples t-test (see awarenesslanguage learning strategies in Table 3), the researchers also found that even though the constructs of awareness level and the level of language learning strategies are relevant, the respondents have a lower degree of awareness than the use of language learning strategies. The results are inconsistent with that of a research study conducted by Yan (2007) which highlighted that attitudinal components are positively correlated with autonomous English learning behavior components. In view of this, a learner should be able to reflect on the positive and negative aspects about a learning event and respond to the judgment after accomplishing one task, such as by engaging in reflective learning journal ( $\mathrm{Du}, 2012)$, diaries (Bhrati, 2004), evaluation sheets (Bhrati, 2004) and so on.

These self-motivated and ongoing learning activities can benefit them in the form of increased competency in communication skills, increased awareness in individual strengths and learning strategies, and the ability to think critically in the age of globalization (Bhrati, 2004).

\section{Difference between Attributes of Self-directed Learning Readiness according to English Proficiency Levels}

To observe the mean differences between proficient and nonproficient students, an independent sample t-test was conducted. The result of the t-test has shown that there was no difference in relation to the three readiness attributes namely, awareness, motivation, and language learning strategies in using self-directed learning strategy among participants from lower proficiency levels (Bands 1, 2, and 3) and upper proficiency levels (Bands 4 and 5) according to participants' MUET results. The results in this study contradicted results that were found in previous studies that higher performing students were likely to have higher SDL readiness scores (Steward, 2007). Similarly, findings in this study were also incompatible with the findings showed proficient learners used more strategy use in terms of metacognitive and social strategies (Salahshour, Sharifib, \& Salahshour, 2013). The results may hint that regardless of proficiency levels, most of them are prone to traditional learning, e.g. lectures, and lack of the ability to conduct their own learning (Chou \& Chen, 2008).

Nevertheless, these results drew a parallel with the investigations of Nordin, Abd Halim and Malik (2016) which illustrated that there 
was no significant difference between academic achievements and SDLR. One possible reason could arise from the lack of exposure to SDL strategies as language instructors, who are concerned with the shortage of time, fast pace of foundation studies and the amount of language materials mandated in the traditional curriculum, might not be able to render sufficient and effective monitoring, feedback and attention on students' achievement in relation to SDL, such as experiences in reflection, self-evaluation and critical thinking skills (Shien \& Akiko, 2009).

\section{CONCLUSION}

In regards to the above findings, the following implications can be made. Firstly, taking into account proficient and non-proficient English language learners in the present study who did not show an advanced level of SDLR, it is hoped that SDL strategies can be embedded in a teacher-led context (at least for the time being) as relying solely on English knowledge through grammar, lecturebased classes, and rote learning is insufficient for the students to achieve the goals of becoming autonomous English language learners. In realizing the underpinning the concept of SDL, learners should engage in critical thinking, creative thinking, reflection and problem-solving, which need to be stressed on in English language learning contexts. Secondly, English language teachers should also acknowledge the salient discrepancies among the readiness of three attributes. That is, while the participants were perceived to be highmotivation leaners, the awareness and the usefulness of autonomous learning strategies, in particular metacognitive strategies-a basic competence required by self-directed learning for successful language learning, seemed to be lacking among respondents. Some notable instructional learner-centered activities can be leveraged to promote both awareness and metacognitive strategies are peer review, reflective learning journals, analysis and synthesis (Shien and Akiko, 2009). In addition, collaboration between students such as giving and receiving peer feedback - especially on tasks studentdirected learning tasks that are based on language environment, task type, gender, and language proficiency - viewed by the interaction model proponents, can be a crucial aspect of interaction that facilitates language learning (Dixon, 2014). Thirdly, an implication for curriculum designers and material developers is that incorporating SDL approaches to syllabi, textbooks, tasks and activities to help 
dependent learners to find a starting point to grasp autonomous learning. Lastly, it is also vital to note that the level of SDLR did not vary based on learners' proficiency levels. In other words, it may be evident that self-directed learning strategies do not tend to give significant impact to the successful academic achievement among high achievers resulting from the existing focus in teaching and learning. On that note, it is highly recommended that the practitioners should reconsider or minimize the traditional educational or paperbased format as it impedes potential self-directed learners who are able to keep up with their linguistic knowledge relevant to the needs and requirements of the current job market.

As such, some structural changes in the curriculum might be considered by including collaborative learning, information searching, as well as oral and written communication, and so on to target learners from both upper and lower English proficiency levels (Wang, 2010; Bhrathi, 2014). For example, Abdussalam Owen and Razali (2018) suggested for ESL/EFL students, such as Malaysian students, and even those who are from outside of Malaysia but studying in Malaysian educational institutions, to be developed a sense of collaborative learning through Communicative Language Teaching (CLT) approaches that promotes diligence and discovery in their learning of the English language. In addition, Razali (2014a, 2014b) also suggested for ESL/EFL teachers to promote the students to engage in informal learning of the English language such as through online popular culture, e.g., reading and writing online fanfiction as well as watching, discussing, reading and writing about online manga and anime, to informally learn and further acquire the English language through the online popular culture and online mediums that they appreciate. Throughout such engagements, students are also likely to undergo a successful role shift to become full autonomous English language learners, which is in line with the mission in the Malaysian National Education Policy Blueprint (2013-2025) to create lifelong learners with autonomous mastery at tertiary level.

There are two major recommendations for future researchers to make further exploration. Due to the quantitative survey research design of the present study, qualitative research in the form of observations or interviews should be further pursued to substantiate the findings in this study with regards to the relationship between SDLR and levels of proficiency. In light of the relatively small scale of this 
present study, future research should include testing respondents in similar foundation programs at other universities throughout the country to produce more generalizable empirical results based on the Malaysian context.

\section{REFERENCES}

Abdussalam Owen, E. \& Razali, A. B. (2018). The effect of communicative activities on Libyan secondary school students' speaking performance in Malaysia. International Journal of Instruction, 11(4), 45-60. 60. DOI: http://dx.doi.org/10.12973/ iji.2018.1144a URL: http://www.e-iji.net/dosyalar/iji_2018_4_4. pdf

Abdullah, M. N. L. Y. (2016). Interaction Effects of Gender and Motivational Beliefs on Self-regulated Learning: A Study at ICT integrated Schools. Malaysian Journal of Learning and Instruction, 13, 25-41.

Abeysekera, L., \& Dawson, P. (2015). Motivation and cognitive load in the flipped classroom: Definition rationale and a call for research. Higher Education Research\& Development, 34(1), $1-14$.

Bharathi, P. (2014). Self - directed learning and learner autonomy in English language teacher education: Emerging trends. International Journal for Teachers of English, 4(1), 1-9.

Chou, P. N., \& Chen, W. F. (2008). Exploratory study of the relationship between self-directed learning and academic performance in a web based learning environment. Online Journal of Distance Learning Administration, 11(1).

Cotterall, S. (1999). Key variables in language learning: What do learners believe about them? System, 27, 493-513.

Deng, D. (2007). An exploration of the relationship between learner autonomy and English proficiency. Asia EFL Journal, 1-23.

Dixon, L. Q. \& Wu, S. (2014). Understanding Language Learning: Review of the Application of the Interaction Model in Foreign Language Contexts. Malaysian Journal of Learning and Instruction, 11, 23-39.

Dong, T., \& Xin, C. (2005). Fostering learner autonomy in English language classroom. CELEA Journal, 28(3), 100-104.

Du, F. (2013). Student perspectives of self-directed language learning: Implications for teaching and research. International 
Journal for the Scholarship of Teaching and Learning, 7(2). Doi:10.20429/ijsotl.2013.070224

Garrison, D. R. (1997). Self-Directed Learning: Toward a

Comprehensive Model. Adult Education Quarterly, 48, 18-33.

Guglielmino, L. M. (1977). Development of the self-directed learning readiness scale (Unpublished doctoral). University of Georgia, USA.

Guglielmino, L. M. (2013). The case for promoting self-directed learning in formal educational institutions. Sa-educ Journal Volume, 10(2).

Holec, H. (1981). Autonomy and foreign language learning. Oxford: Perganon.

Karlak, M., \& Velki, T. (2015). Motivation and learning strategies as predictors of foreign language communicative competence. Croatian Journal of Education, 17(3),635-658.

Kerka,S.(1997).Constructivism, workplace learning, and vocational education. New York: ERIC Document Reproduction.

Khodabandehlou, M., Jahandar, S., Seyedi, G., \& Abadi, R. M. D. (2012).The impact of self-directed learning strategies on reading comprehension. Retrieved from http://www.ijser.org/ paper/The-Impact-of-Self-directed-Learning-Strategies-onReading-Comprehension.html

Knowles, M. S. (1975). Self-directed learning: A guide for learners and teachers. New York: Association Press.

Kocak, A. (2003). A study on learners' readiness for autonomous learning of English as a foreign language. Retrieved from https://etd.lib.metu.edu.tr/upload/1217728/index.pdf

Kuah, G. (2017). UPM Offers Foundation Pathway for SPM-holders to Study at The University / Universiti Putra Malaysia.Upm. edu.my. Retrieved from http://www.upm.edu.my/news/upm offers_foundation_pathway_for_spm_holders_to_study_at_ the_university-24921? L=en

Little, D. (1990). Autonomy in language learning: Some theoretical and practical considerations in I. Gathercole (Eds.), Autonomy in Language Learning, 7-15. Great Britain: Bourne Press.

Littlewood, W. (1999). Defining and Developing Autonomy in East Asian Contexts. Applied Linguistics, 20 (1), 71-94.

Malaysian Education Blueprint 2013-2025 (Preschool-PostSecondary Education). (2013). Retrieved from http://www. moe.gov.my/images/dasar-kpm/articlefile_file_003108.pdf

Mahboobe, F. (2014). From spoon feeding to self-feeding: Are Iranian EFL learners ready to take charge of their own learning? 
Electronic Journal of Foreign Language Teaching, 11 (1), pp. 98-115.

Mahdavinia, M., \& Nabatchi, A.L. (2011). Portfolio assessment: A tool for self-directed learning at post-secondary level. In D. Gardner (Ed.), Fostering autonomy in language learning (pp. 76-90). Gaziantep: Zirve University.

Mohamadpour, P. (2013). Realization of autonomy and English language proficiency among Iranian high school students. Theory and practice in language studies, 3(7). Retrieved from http://dx.doi.org/10.4304/tpls.3.7.1187-1193

MUET - Portal Rasmi Majlis Peperiksaan Malaysia. (2017). Portal. mpm.edu.my. Retrieved from http://portal.mpm.edu.my/en/ muet1

Nordin, N., Abd Halim, N., \& Malik, M. (2016).Assessing readiness for self-directed learning among college students in the provision of higher learning institution. EnvironmentBehaviour Proceedings Journal, 1(3). Doi: 10.21834/e-bpj. v1i3.296

Nunan, D. (1988). Syllabus Design. Oxford: Oxford University Press.

O’Malley, J. M., \& Chamot, A. U. (1987). The cognitive academic language learning approach: A bridge to the mainstream. TESOL Quarterly, 21, 227-249.

Razali, A. B. (2014a). Online manga and anime in promoting language learning and literacy practices. In Liu, C. C. et al. (Eds.) Proceedings of the 22nd International Conference on Computers in Education, Japan: Asia-Pacific Society for Computers in Education (pp. 756-761).

Razali, A. B. (2014b). Online popular culture in language learning: Reading and writing online fanfiction. In Liu, C. C. et al. (Eds.) Proceedings of the 22nd International Conference on Computers in Education, Japan: Asia-Pacific Society for Computers in Education (pp. 762-767).

Reeve, J. (2009). Why teachers adopt a controlling motivating style toward students and how they can become more autonomy supportive. Educational Psychologist, 44, 159-175. Doi: 10.1080/00461520903028990

Reio, T. G. (2003). Prior knowledge, self-directed learning readiness, and curiosity: Antecedents to classroom learning performance. International Journal of Self-Directed Learning, 1(1), 18-25.

Rivero, M. M. J., Urquía, G. E., López, S. P., \& Camacho, M. M. M. (2017). Motivation and learning strategies in accounting: 
Are there differences in English as a medium of instruction (EMI) versus non-EMI students? Revista De Contabilidad. Doi:10.1016/j.rcsar.2017.04.002

Reinders, H. (2010). Towards a classroom pedagogy for learner autonomy: A framework of independent language learning skills. Australian Journal of Teacher Education, 35(5), 39-55. Doi: http://dx.doi.org/10.14221/ ajte.2010v35n5.4

Saleh, S. E. \& Tork, H. M. (2013).Critical thinking and self-directed learning as an outcome of problem-based learning among nursing students in Egypt and Kingdom of Saudi Arabia. Journal of Nursing Education and Practice, 3 (7), 103-110. Retrieved from www.sciedu.ca/journal/index.php/jnep.

Salahshour,F., Sharifib,M.,\& Salahshour,N.(2013). The relationship between language learning strategy use, language proficiency level and learner gender. Procedia - Social and Behavioral Sciences, 70, $634-643$.

Scharle, A. \& Szabo, A. (2000).Learner autonomy: A guide to developing learner responsibility. Cambridge: Cambridge University Press.

Shien, S., \& Akiko, T. (2009).Relationship between learner autonomy and English language proficiency of Japanese learners. The Journal of Asia TEFL, 6(3), 297-325.

Sinclair, B., I.McGrath, T. Lamb (1999). Learner Autonomy, Teacher Autonomy: Future Directions. Longman.

Spratt, M., Humphreys, G. and Chan, V. (2002). Autonomy and Motivation: Which comes first? Language Teaching Research, 6 (3), 245-266.

Stewart, R. A. (2007). Evaluating the self-directed learning readiness of engineering undergraduates: a necessary precursor to project-based learning. World Transactions on Engineering and Technology Education, 6(1).

Tudor, I. (1996). Teacher roles in the learner-centered classroom. ELT Journal, 47(1), 23-24.

Wang, J. (2010). How to Develop College Students' Autonomous English Learning Skills ---Take Reading Course in JointProgram in HCFT as an Example. English Language Teaching, 3(3). Retrieved from http://dx.doi.org/10.5539/elt.v3n3p221

Wenden, A. (1991). Learner strategies for learner autonomy. Hertfordshire: Prentice Hall International Ltd.

Williamson, S. N. (2007). Development of a self-rating scale of self-directed learning. Nurse Researcher, 14(2), 66-83. Retrieved from https://www. researchgate. net/...Williamson/...self... self directed_learning/.../562756f6 
Wiley, K. (1983). Effects of a self-directed learning project and preference for structure on self-directed learning readiness. Nursing Research, 32, 181-185. Doi: 10.1097/00006199198305000-00011

Wolters, C. (2003) Regulation of motivation: evaluating the underemphasized aspect of self-regulated learning. Educational Psychologist, 34(4), 189-205.

Yan, G. (2007). Autonomous English learning among postgraduate EFL learners in China: A study of attitudes and behaviors. The Journal of Asia TEFL, 4(3), 47-70. 